\title{
Impact of disease and detachment on growth and survivorship of sea fans Gorgonia ventalina
}

\author{
Carlos Toledo-Hernández ${ }^{1, *}$, Paul Yoshioka ${ }^{2}$, Paul Bayman ${ }^{1}$, Alberto M. Sabat ${ }^{1}$ \\ ${ }^{1}$ Department of Biology, University of Puerto Rico-Río Piedras, PO Box 23360, San Juan 00931, Puerto Rico \\ ${ }^{2}$ Department of Marine Sciences, University of Puerto Rico-Mayagüez, San Juan 00681, Puerto Rico
}

\begin{abstract}
The importance of diseases of sea fans (Gorgonia spp.) is widely recognized; however, previous studies have not always distinguished between causes of mortality and differential effects of disease on different size clases of sea fans. In this study, mortality and net growth of healthy, purple-spotted and diseased Gorgonia ventalina colonies of small, medium and large size were estimated for 1 yr. Detachment occurred in all size and health categories. Mortality due to disease was exclusively observed in small colonies. Colony growth was influenced by health state and size. While medium and large colonies of all health states exhibited negligible net growth, small diseased colonies exhibited negative net growth. In this group, disease was an important cause of tissue loss, while in all 3 health states the main cause was fracture. Most healthy colonies that became diseased passed through the purple-spotted state. The rate at which purpled colonies returned to being healthy was double the rate at which they advanced to diseased, which then rarely recovered. Disease did not significantly impact growth or survivorship of medium and large colonies, but its effect on smaller fans is significant for populations because it reduces the transition to sizes that are reproductively active.
\end{abstract}

KEY WORDS: Aspergillosis · Gorgonia ventalina $\cdot$ Growth rate $\cdot$ Mortality rate $\cdot$ Coral diseases Resale or republication not permitted without written consent of the publisher

\section{INTRODUCTION}

Diseases are one of the major factors currently contributing to the decline of coral reefs (Nugues 2002). The first reported coral disease, black band disease, was described early in the 1970s (Antonius 1977). Since then reports of new coral diseases have dramatically increased (Gardner et al. 2003). In the Caribbean alone, at least 15 coral diseases have been reported in the last 2 decades (Goreau et al. 1998). Early reports focused on describing disease manifestations and prevalence. Recent studies have shifted their focus towards the microbiology of these diseases with the aim of identifying pathogens (Pantos et al. 2003, Ainsworth et al. 2007). However, the lack of proper multidisciplinary approaches to coral diseases (including sea fan aspergillosis) has produced confusion over interpretation of results (Work et al. 2008).

Early reports of sea fan aspergillosis (Smith et al. 1996, Nagelkerken et al. 1997, Geiser et al. 1998, Goreau et al. 1998) attributed the 1980s sea fan mass mortality events that occurred in the Caribbean to this disease (Guzmán \& Cortés 1984, Garzón-Ferreira \& Zea 1992). Since the mass mortalities were noticed a posteriori of the events with only the massive numbers of sea fan skeletons as evidence, it was not possible to collect the data needed to link these mass mortality events to aspergillosis or any other cause. Since then only 3 studies have documented the impacts of aspergillosis on the vital rates of Gorgonia ventalina colonies (i.e. fecundity, growth and survival). Petes et al. (2003) reported complete reproductive suppression in fans showing signs of aspergillosis. Kim \& Harvell (2004) documented a reduction in colony median height, from 40 to $26 \mathrm{~cm}$ in sea fan populations in the Florida Keys after an aspergillosis epizootic event, and Kim et al. (2006) reported that sea fan mortality increased between 46 and $95 \% \mathrm{yr}^{-1}$ after an aspergillosis outbreak.

Even though these studies support the hypothesis that aspergillosis can significantly impact the vital rates of Gorgonia ventalina, the differential effect on 
growth and mortality of colonies of different sizes has been overlooked. In addition, confusion between mortality caused by aspergillosis and factors other than disease permeates the literature. This uncertainty can result in the erroneous impression that aspergillosis is the only cause of sea fan mortality, or that other causes of mortality are irrelevant. Similarly, no distinction has been made regarding the effect on growth and mortality of fans exhibiting what are considered to be different manifestations of aspergillosis such as galls, tumors, or purple spots. This is important because these features may not exclusively be the result of fungal infections; for example, tumors in sea fans can also result from encapsulation of filamentous algae (Morse et al. 1981).

In the present study the growth and mortality rates of 150 Gorgonia ventalina colonies of different size classes and health states (diseased, purple-spotted and healthy) were measured for 1 yr. From a population perspective, determining which size category is most affected by a disease is very important. Survivorship and growth in some Caribbean gorgonians are strongly size-dependent, with the highest mortality and fastest growth occurring in small colonies (Yoshioka \& Yoshioka 1987). The refuge size hypothesis states that small colonies should grow as fast as possible until reaching a refuge size (Yoshioka \& Buchanan-Yoshioka 1991, Yoshioka 1996). However if disease significantly reduces colony growth, disease in small colonies will have a greater demographic effect than in larger ones because it may prevent transition into the refuge size. On the other hand, small colonies have been reported to have enhanced chemical defenses against aspergillosis relative to larger ones (Dube et al. 2002); if so, growth of diseased lesions in small colonies should be slower than in larger ones, and thus mortality due to disease (i.e. complete decimation of healthy tissue by disease), should be lower in smaller fans. Moreover, if purple spots are an early sign of disease as has been suggested for sea fan aspergillosis (Petes et al. 2003, Alker et al. 2004, Mullen et al. 2006), then a proportion of these spots should progress into the full manifestation of the disease, and colonies with purple spots should exhibit slower growth rates as compared to healthy ones, due to allocation of energy or other limited resources towards an immune response. Finally, it has been shown that for scleractinian coral colonies with a higher proportion of lesions to healthy tissue, recovery is lower than in colonies with a smaller proportion of lesion to healthy tissue (Oren et al. 1997, Lirman 2000). If the same applies to gorgonians, it is predicted that for colonies having relatively big lesions, lesion size should increase at a faster rate than in colonies with relatively small lesions.
The present study addresses 2 specific questions. (1) Do growth and mortality differ among colonies of different health states and size categories? (2) Are changes in lesion size associated with initial colony and initial lesion size?

\section{MATERIALS AND METHODS}

Study locations and sampling. This study was conducted in 3 hard ground habitats located on the eastern coast of Puerto Rico. At these sites, 150 colonies of Gorgonia ventalina were selected within a $50 \mathrm{~m} \times 6 \mathrm{~m}$ area between 3 and $4 \mathrm{~m}$ deep; a balanced design with a similar number of colonies representing each health state (healthy, diseased or purpled) and size category (small, medium and large) was sought. Healthy sea fans $(\mathrm{H})$ were defined as those with no gross lesions or purpled spots. Purpled sea fans (P) were defined as having one to several dark purple spots without polyps, but no necrotic tissue (Kim et al. 2006). Diseased sea fans (D) were defined as colonies with at least one type I injury, e.g. exposed skeleton surrounded by a purple halo (Toledo-Hernández et al. $2007 \mathrm{~b}$ ) and in some cases purpled spots. Although this criterion has been used previously to describe sea fan aspergillosis (i.e. necrotic tissue surrounded by a purple halo), the use of the term aspergillosis is avoided because the pathogen(s) were not identified; moreover, the use of 'aspergillosis' implies that the pathogen is Aspergillus sydowii, which is not always the case (Toledo-Hernández et al. 2007a, 2008). Colonies with other types of conditions such as type II lesions (e.g. with the skeleton overgrown by fouling organisms without a ring of purpled tissue [Toledo-Hernández et al. 2007b], those with signs of predation by Cyphoma spp. or with tissue overgrown by fire corals) were excluded from the sample, as the main focus of this study was to contrast growth and mortality between healthy, purpled and diseased colonies.

Small colonies were defined as those with a surface area of healthy tissue $<500 \mathrm{~cm}^{2}$, medium colonies as those with a healthy tissue area between 501 and $1000 \mathrm{~cm}^{2}$, and large colonies as those with an area $>1000 \mathrm{~cm}^{2}$. Colonies were numbered with aluminum tags fixed to the base; a gridded acrylic sheet was temporarily placed behind the colony to provide a background against which the size and shape of the colony could be clearly defined and photographed (using a high resolution digital camera in an underwater housing). Sea fans were initially photographed between July and September 2006, and subsequently photographed every 3 mo until October 2007.

Growth estimation. SigmaScan Pro Image Measurement Software (Systat Software) was used to estimate 
areas of healthy tissue $\left(\mathrm{H}_{t}\right)$ in $\mathrm{cm}^{2}$ and when present, diseased $\left(\mathrm{D}_{t}\right)$ and purpled $\left(\mathrm{P}_{t}\right)$ tissues at observation period $t$. Total colony area $(\mathrm{C})$ at observation period $t$ equals:

$$
\mathrm{C}_{t}=\mathrm{H}_{t}+\mathrm{D}_{t}+\mathrm{P}_{t}
$$

Daily growth rate of healthy tissue (Gh) was calculated as:

$$
\mathrm{Gh}=\left(\mathrm{H}_{\mathrm{f}}-\mathrm{H}_{\mathrm{i}}\right) / \mathrm{T}
$$

where $\mathrm{H}_{\mathrm{f}}$ is the healthy tissue area at the final observation period, $\mathrm{H}_{\mathrm{i}}$ is the healthy tissue area at the initial observation period, and $\mathrm{T}$ is number of days between initial and final dates. Daily growth rate of tissue purpling (Gp) was calculated as:

$$
\mathrm{Gp}=\left(\mathrm{P}_{\mathrm{f}}-\mathrm{P}_{\mathrm{i}}\right) / \mathrm{T}
$$

where $P_{f}$ is the purpled tissue area at the final observation period, $\mathrm{P}_{\mathrm{i}}$ is the purpled tissue area at the initial observation period. Daily growth rate of diseased tissue (Gd) was calculated as:

$$
\mathrm{Gd}=\left(\mathrm{D}_{\mathrm{f}}-\mathrm{D}_{\mathrm{i}}\right) / \mathrm{T}
$$

where $D_{f}$ is the diseased tissue area at the final observation period, $D_{i}$ is the diseased tissue area at the initial observation period. The daily rate of fragmentation of healthy tissue $(\mathrm{F})$ was estimated as:

$$
\mathrm{F}=\left(\mathrm{C}_{\mathrm{f}}-\mathrm{C}_{\mathrm{i}}\right) / \mathrm{T}
$$

where $\mathrm{C}_{\mathrm{f}}$ is the total colony area at the final observation period and $C_{i}$ is the total colony area at the initial observation period. This estimate of fragmentation is a conservative one, because it only considers colonies which showed a net loss in healthy tissue that was not accounted for by an increase in lesion or purpled tissue areas.

Colony mortality. Colony death due to disease was defined as a colony that remained attached to the substrate but lost all healthy tissue due to an increase in lesion area. Also, several colonies with diseased lesions covering $>75 \%$ of the total colony area that disappeared from the study transects were scored as dying due to disease. All other colonies that disappeared from the study transect were assumed to have detached from the substrate due to wave action. Although detachment does not cause immediate death to a colony, it was assumed that detached colonies were either thrown ashore (Birkeland 1974), or tumbled to the reef base and smothered by sediments. In either case, detachment eventually leads to death (i.e. total loss of healthy tissue).

Statistical analysis. To standardize Gh, Gp, and Gd as a function of the initial healthy tissue area $\left(\mathrm{H}_{\mathrm{i}}\right), \mathrm{Gh}$, Gp, and Gd, were divided by $\mathrm{H}_{\mathrm{i}}$ (e.g. $\mathrm{PGh}=\mathrm{Gh} / \mathrm{H}_{\mathrm{i}}$ ). Kruskal-Wallis non-parametric ANOVA was used to test for differences between: PGh (as the dependent variable) and health state-colony size (as the independent variables); PGp among purpled small, medium and large colonies, and among diseased small, medium and large colonies; and F vs. healthy state and colony size. Kruskal-Wallis ANOVA was also used to test for differences between loss of healthy tissue in diseased colonies (dependent variable), and the causes of these losses (e.g. fragmentation, purpling and disease) as the independent variables. Spearman correlation analyses were conducted to determine if the initial proportion of purpled to healthy tissue $\left(\mathrm{P}_{\mathrm{i}} / \mathrm{H}_{\mathrm{i}}\right)$ affects PGp, and if the proportion of diseased to healthy tissue $\left(\mathrm{D}_{\mathrm{i}} / \mathrm{H}_{\mathrm{i}}\right)$ affects PGd. Chi-squared tests were used to determine differences in relative mortality between health condition and size class, and to determine differences between cause of mortality (detachment and disease) and health state.

\section{RESULTS}

\section{Mortality}

Of the 150 colonies initially tagged and photographed, 31 were excluded from the analyses because their tags were lost and their fates were uncertain. Of the remaining 119 marked sea fans, 27 died during the study. Mortality was size-dependent, with the probability of death higher in small sea fans $(38.6 \%)$ than in medium $(11.1 \%)$ and large $(3.8 \%)$ ones $\left(\chi^{2}=16.7 ; \mathrm{df}\right.$ $=2 ; \mathrm{p}<0.001$, Table 1$)$. In addition, diseased fans died at a higher rate $(44.0 \%)$, than healthy $(20.9 \%)$ or purpled $(7.4 \%)$ ones (Table 1$)$. These differences were also statistically different $\left(\chi^{2}=10.2 ; \mathrm{df}=2 ; \mathrm{p}=0.006\right)$. Two causes of mortality were observed: total loss of healthy tissue due to an increase in disease lesion area $(37.1 \%)$ and detachment $(62.9 \%)$. Fatalities due to dis-

Table 1. Gorgonia ventalina. Observed frequency of living and dead G. ventalina of different size categories: (S) small, (M) medium, (L) large, and health states (H) healthy, (P) purpled,(D) diseased, during the 1 yr study period

\begin{tabular}{|lccc|}
\hline Category and state & Alive (n) & Dead (n) & Total (n) \\
\hline SH & 22 & 9 & 31 \\
SP & 6 & 2 & 8 \\
SD & 7 & 11 & 18 \\
MH & 18 & 4 & 22 \\
MP & 8 & 0 & 8 \\
MD & 6 & 0 & 6 \\
LH & 13 & 1 & 14 \\
LP & 11 & 0 & 11 \\
LD & 1 & 0 & 1 \\
Total & 92 & 27 & 119 \\
\hline
\end{tabular}


Table 2. Gorgonia ventalina. Observed frequency of causes of mortality (disease or detachment) of different size categories, (S) small, (M) medium and (L) large, and health states (H) healthy, (P) purpled, (D) diseased. MP, MD, LH and LD had 0 frequency

\begin{tabular}{|lrcr|}
\hline Category and state & Disease & Detachment & Total \\
\hline SH & 0 & 9 & 9 \\
SP & 0 & 2 & 2 \\
SD & 10 & 1 & 11 \\
MH & 0 & 4 & 4 \\
LH & 0 & 1 & 1 \\
Total & 10 & 17 & 27 \\
\hline
\end{tabular}

Table 3. Gorgonia ventalina. Transition table showing observed frequencies of change in health state. between initial $\left(t_{\mathrm{i}}\right)$ and final $\left(t_{\mathrm{f}}\right)$ dates

\begin{tabular}{|lcrcr|}
\hline & \multicolumn{4}{c}{} \\
\cline { 2 - 5 }$t_{\mathrm{f}}$ & Healthy & Purpled & & \\
\cline { 3 - 5 } & & 5 & 2 & 49 \\
Healthy & 42 & 18 & 2 & 27 \\
Purpled & 7 & 2 & 10 & 16 \\
Diseased & 4 & 2 & 11 & 27 \\
Dead & 14 & 27 & 25 & 119 \\
Total & 67 & & & \\
\hline
\end{tabular}

ease were only recorded in small colonies (Table 2). Detachment was recorded in all sizes, but more so in small fans than in medium or large ones (Table 2). Healthy sea fans detached proportionally more than diseased or purpled ones $\left(\chi^{2}=24 ; \mathrm{df}=2 ; \mathrm{p}<0.001\right)$.

\section{Health state dynamics}

Approximately $65 \%$ of the colonies that started the study as healthy or purpled remained so 1 yr later, whereas only $40 \%$ of the diseased colonies remained in this state (Table 3). The probability that a healthy colony changed to the purpled condition was double the rate at which they advanced to diseased state. The rate at which purpled colonies returned to being healthy was more than twice the rate at which they advanced to the diseased state. Diseased colonies rarely reversed to either the purpled or healthy state: most stayed diseased or died (Table 3).

\section{Colony size dynamics}

Overall, most colonies (55\%) manifested tissue loss. Small diseased colonies had significantly more tissue

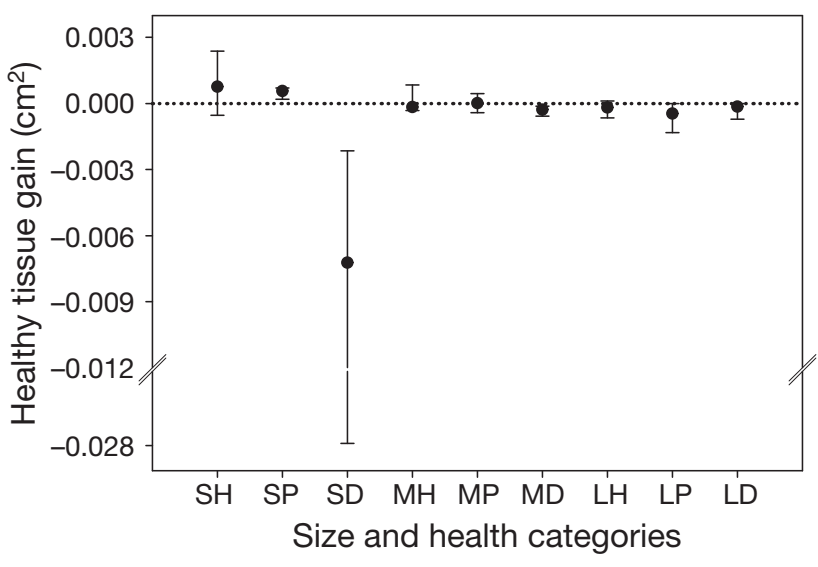

Fig. 1. Gorgonia ventalina. Effects of colony size and health state on the median proportional net growth rate of healthy tissue. Bars show lower and upper quartiles. (S) small, (M) medium, (L) large, (H) healthy, (P) purpled, (D) diseased sea fans

loss than other groups $\left(H_{(8,101)}=39.9, \mathrm{p}<0.0001\right.$; Fig. 1). Three causes of healthy tissue loss were recorded: tissue fragmentation $(\mathrm{F})$, purpling $(\mathrm{P})$ and disease (D). Since tissue fragmentation occurred in all size classes and health states, it was asked whether tissue fragmentation varied significantly across size classes and health states: it did. Small colonies, and particularly small-diseased ones, suffered significantly more tissue loss due to fragmentation than the rest $\left(H_{(8,50),}=15.85, \mathrm{p}=0.044\right.$, Table 4$)$. Loss of healthy tissue due to purpling was negligible and did not differ among colony size classes, nor between purpled and diseased colonies $\left(H_{(5,57),}=5.76, \mathrm{p}=\right.$ 0.3302). Within diseased colonies, loss of healthy tissue due to disease and fracture was significantly higher than that due to purpling $\left(H_{(2,34)}=8.29, \mathrm{p}<\right.$ 0.015 , Table 4).

Table 4. Gorgonia ventalina. Healthy tissue loss due to fragmentation, purpling and disease of different health states: $(\mathrm{H})$ healthy, $(\mathrm{P})$ purpled, and (D) diseased, and size classes (S) small, (M) medium, and (L) large. Numbers represent median daily loss in $\mathrm{cm}^{2}$ plus lower and upper quartiles in parenthesis, at $10^{3}$

\begin{tabular}{|llll|}
\hline \multicolumn{2}{|c}{ Fragmentation } & \multicolumn{1}{c|}{ Purpling } & Disease \\
\hline SH & $1.143(0.641,1.76)$ & & \\
MH & $0.307(0.182,0.8)$ & & \\
LH & $0.411(0.163,0.668)$ & & \\
SP & $0.202(0.093,0.311)$ & $-0.209(-0.686,0.739)$ & \\
MP & $0.437(0.384,0.478)$ & $-0.180(-1.01,1.369)$ & \\
LP & $0.950(0.029,1.477)$ & $0.007(-0.609,0.707)$ & \\
SD & $2.54(1.43,3.83)$ & $-0.028(-0.126,0.008)$ & $2.32(-0.051,10.204)$ \\
MD & $0.387(0.163,0.768)$ & $0.003(-0.001,0.043)$ & $0.025(-0.354,0.062)$ \\
LD & $0.245(0.035,0.0949)$ & $0.011(0.008,0.012)$ & $0.001(-0.007,0.125)$ \\
\hline
\end{tabular}


Initial relative amount of diseased area $\left(\mathrm{Ad}_{1} / \mathrm{Ah}_{1}\right)$ was not associated with change in lesion size during the study period $(\mathrm{Gd})(\mathrm{r}=0.322 ; \mathrm{df}=27 ; \mathrm{p}=0.101)$, but Gp was negatively associated with the relative amount of initial purpled area $(\mathrm{r}=-0.577$; $\mathrm{df}=28 ; \mathrm{p}=0.001)$.

\section{DISCUSSION}

\section{Mortality}

The current view is that given no aspergillosis outbreak, baseline sea fan mortality is low $(<10 \%)$, increasing dramatically to close to $100 \%$ during an outbreak (Kim et al. 2006). However, prior to the advent of aspergillosis other significant causes of sea fan mortality were reported: detachment (Birkeland 1974, Yoshioka \& Yoshioka 1991), overgrowth by Millepora spp., Desmopsamma anchorata and Haliclona viridis (Yoshioka \& Yoshioka 1991), and smothering by horizontal sediment movement (Yoshioka \& Yoshioka 1987, 1989, Gotelli 1988).

In the present study, 2 sources of sea fan mortality were recorded: detachment and death due to disease. Detachment was the main source of mortality, and even though it affected sea fans of all sizes and health states, it was particularly high in small healthy colonies. This result is somewhat surprising, because if resistance to drag-force increases with colony size (Lasker et al. 2003), more detachment in larger colonies would be expected than in smaller ones. However, these results are consistent with previous studies that also report relatively more detachment in small Gorgonia ventalina colonies (Birkeland 1974). A plausible explanation for these results could be that the holdfasts of small colonies have smaller surface area in contact with the substrate, making them more susceptible to detachment. Another unexpected result was the fact that detachment was significantly higher in healthy colonies as compared to purpled and diseased colonies. The authors have no biological explanation for this; it is possible that increasing the number of purpled and diseased fans surveyed may help clarify this result.

The other cause of mortality, death due to disease, was exclusively observed in small colonies. Several field studies have reported higher aspergillosis prevalence in larger sea fans than in smaller ones (Nagelkerken et al. 1997, Jolles et al. 2002 Kim \& Harvell 2004, Mullen et al. 2006), suggesting that smaller fans are more resistant to aspergillosis, perhaps because small fans may be better chemically defended against aspergillosis than mature and large ones (Dube et al. 2002). However, the conclusions of these studies are based on disease prevalence rather than mortality, and if mortality among small fans is as fast as the data collected in the present study suggests $(<3 \mathrm{mo})$, a small healthy fan can get infected and die without being counted as diseased if time between censuses is $>3$ mo. This could give the erroneous impression of a low prevalence of aspergillosis among small fans.

\section{Size dynamics}

Growth in modular-colonial marine invertebrates such as gorgonians is a highly variable process controlled by (1) coral astogeny (Lasker \& Sánchez 2002) and (2) abiotic factors, such as nutrient concentration (Atkinson et al. 1995, Kim \& Lasker 1997), thermal stress (Goreau \& Macfarlane 1990, Jokiel \& Coles 1990), light levels (Huston 1985, Jokiel \& Coles, 1990), water pH (Wilkinson 1999), and water flow (Birkeland 1974, Sebens 1984, Dai \& Lin 1993) among others. These factors acting together may contribute towards tissue gain or loss. However, until now no attempt had been made to examine the extent that health state and colony size influence growth.

In the present study the gain and loss of healthy tissue was very variable; nonetheless, most colonies remained near size equilibrium (i.e. gaining and losing roughly the same amount of tissue area). Other studies have also reported high variability in growth rates among gorgonians. For instance, mean growth rates of $1.6 \mathrm{~cm}^{2} \mathrm{~d}^{-1}$ with a coefficient of variation of $116 \%$ (calculated with the upper $95 \%$ confident interval) were reported for Gorgonia ventalina colonies (Birkeland 1974); Yoshioka \& Yoshioka (1991) reported mean growth rates in $G$. ventalina heights of $1.92 \mathrm{~cm} \mathrm{~d}^{-1}$, with a coefficient variation of $105.2 \%$. To explain this highly variable phenomenon, it is necessary to understand the processes and factors that add and remove tissue in modular-colonial marine invertebrates.

Our data indicate that sea fan net growth was not strongly related to initial colony size or health state, but was strongly related to their interaction. Only small diseased colonies significantly varied from zero net growth, and the deviation was attributed to a net tissue loss due to disease and fracture, rather than a net tissue gain (further discussion on this topic below). Sizeindependent growth has also been reported in the gorgonian genus Pseudopterogorgia (Yoshioka 1994). However, size-dependent growth was found in Leptogorgia virgulata and P. elisabethae (Gotelli 1988, Lasker et al. 2003). Discrepancies regarding the sizedependency of growth among gorgonians are related to the nature of the factors that add and remove tissue from corals. Most likely the processes that add tissue are strongly size-based (Gotelli 1988, Lasker et al. 2003); but apart from disease, many of the processes 
that remove tissue are abiotic (e.g. high energy events), and thus potentially size-independent.

Three causes of healthy tissue loss were recorded: tissue fragmentation, purpling and disease. Fragmentation of healthy tissue occurred in all size classes and health state conditions; it was the sole cause of healthy tissue loss in healthy colonies and the main cause in purpled and diseased colonies. Tissue fragmentation has been reported by a previous study as an important factor controlling growth of sea fans, particularly in small colonies (Birkeland 1974). Skeletons in smaller fans are thinner than in larger ones (Toledo-Hernández, unpubl. data), and thicker skeletons withstand the drag and bending produced by hydrodynamic forces better than thinner ones (Chang et al. 2007). The importance of fragmentation as a cause of tissue loss is likely to vary temporally and spatially. For example, less fragmentation in the back reef and during calm periods would be expected than in the front reef during a high surf event. Disease was only a significant cause of healthy tissue loss in small colonies, the majority (10 out of 14 colonies) of which died. These results suggest that small diseased colonies failed to contain lesion growth, and they died rather quickly because the rate of healthy tissue gain was much lower than the rate of healthy tissue loss due to disease. Purpling had a negligible effect on loss of healthy tissue.

\section{Health state transitions}

Diseased colonies rarely recuperated (i.e. returned to either the purple or healthy state); most remained in either the diseased state or died. In the cases where diseased colonies survived, which were only the medium and large colonies, lesions were contained (i.e. lesions did not increase in area). This suggests that the immune system of medium and large sea fans can successfully contain the progression of disease. Moreover, the immune system might effectively eradicate the disease, but cannot regenerate the lost tissue because of colonization of the exposed skeleton by fouling organisms (Kim et al. 2006); under this scenario, the colonies cannot be considered healthy, but colonies with type II lesions sensu Toledo-Hernández et al. (2007a).

The majority of colonies that acquired disease lesions during the observation period passed through the purpled state. This suggests that purpling is either an early manifestation of an infectious disease, e.g. aspergillosis (Kim et al. 2006), or an infection caused by a weak pathogen which facilitates a secondary infection by another pathogen resulting in tissue necrosis. Alternatively, purpling could be caused by non-infectious agents (Morse et al. 1981, Alker et al. 2004) that may weaken the immune system of the sea fans, thus leading to lesion formation.

\section{CONCLUSIONS}

Disease and detachment impact the survivorship and growth of sea fans; however, their relative importance may change temporally and spatially. In the present study mortality due to disease was $<10 \%$ and only affected small fans. Nonetheless, during a disease outbreak mortality can reach massive levels and affect sea fans of all sizes (Kim et al. 2006). Similarly, mortality due to detachment affected mainly small sea fans, but was higher than that due to disease. The importance of detachment as a source of mortality should decrease with depth, and from the fore to the back reef. Study sites were relatively shallow (3 to $4 \mathrm{~m}$ ) and located in what could be considered the crest, thus explaining the high levels of detachment observed. However, under periods of extreme water flow such as hurricanes, mortality due to detachment can be devastating for sea fans located deeper and of all sizes (Yoshioka \& Yoshioka 1989).

A combination of high small fan mortality and slow diseased fan growth rate may have serious repercussions for sea fan populations: high mortality and reduced growth rates will reduce the transition to adulthood, decreasing the number of reproductively active sea fans. The growth response of purpled fan colonies was more similar to the response of healthy fans than to the response of diseased ones: most purpled colonies exhibited net positive growth and the main cause of tissue loss was fragmentation, not purpling. Several authors have suggested that purple spots are a manifestation of aspergillosis (Kim et al. 2006). It is shown here that purpled colonies can make the transition to the diseased state, indicating that the purpled state can indeed lead to disease. The fact that growth and survivorship in purpled colonies was similar to that of healthy colonies could be explained by the fact that total purpled area was almost zero, and thus it should have a negligible effect on the colony physiology.

The present study had several methodological constraints which merit comment. The monitoring interval allowed the estimation of colony mortality and growth with enough accuracy to distinguish between causes of mortality and the different factors involved in tissue gain and loss. However, given the highly dynamic nature of the processes involved in growth and survival of sea fans, 3 mo is probably not frequent enough to explain all the variability observed. For instance, detachment rate might be overesti- 
mated if an initially healthy colony became diseased and died due to the disease, but subsequently detached leaving no evidence of its presence before the next visit: such a colony would have been scored as having died due to detachment rather than to disease. The same can be argued for growth: a colony can lose and then gain tissue several times in a 3 mo interval without being detected. Because of this, the rate of tissue fracture might be underestimated. These results differ in some respects from previous studies of the effects aspergillosis on sea fans, suggesting that different diseases with similar signs might be involved.

Acknowledgements. This project was supported by UPR Sea Grant (NOAA award NA16RG2278, project R-92-1-04; NOAA award NA170P2919), NIH SCoRE (2S06GM08102), NSF CREST (HRD0734826), and NOAA-CRES (NA170P2919). CTH thanks the RISE-NIH program for a research fellowship (2 R25 GM061151) and the International Society for Reef Studies (ISRS) for an ISRS/TOC Coral Reef ConservationAward (2006).

\section{LITERATURE CITED}

Ainsworth TD, Kramasky-Winter E, Loya L, Hoegh-Guldberg O, Fine M (2007) Coral disease diagnostics: What's between a plague and band? Appl Environ Microbiol 73: 981-992

Alker AP, Smith GW, Kim K (2004) Localized induction of a generalized response against multiple biotic agents in Caribbean sea fans. Coral Reefs 23:397-405

Antonius A (1977) Coral mortality in reefs: a problem of science and management. Proc 3rd Int Coral Reef Symp 2: $618-623$

Atkinson MJ, Garson B, Crow GL (1995) Coral growth in high nutrient, low pH sea water: a case study of coral culture at the Waikiki Aquarium, Honolulu Hawaii. Coral Reefs 14: 215-223

Birkeland C (1974) The effect of wave action on the population dynamics of Gorgonia ventalina (Linnaeus). Stud Trop Oceanogr 12:115-126

> Chang WL, Chi KJ, Fan TY, Dai CF (2007) Skeletal modification in response to flow during growth in colonies of the sea whip Junceella fragilis. J Exp Mar Biol Ecol 347: 97-108

Dai CF, Lin MC (1993) The effects of flow on feeding of three gorgonians from southern Taiwan. J Exp Mar Biol Ecol 173:57-69

Dube D, Kim K, Alker AP, Harvell CD (2002) Size structure and geographic variation in chemical resistance of sea fan corals Gorgonia ventalina to a fungal infection. Mar Ecol Prog Ser 231:139-150

Gardner TA, Côté IM, Gill JA, Grant A, Watkinson AR (2003) Long-term region-wide declines in Caribbean corals. Science 301:958-960

Garzón-Ferreira J, Zea JS (1992) A mass mortality of Gorgonia ventalina (Cnidaria: Gorgonidae) in the Santa Marta area, Caribbean coast of Colombia. Bull Mar Sci 50: 522-526

Geiser DM, Taylor JW, Ritchie KB, Smith GW (1998) Cause of sea fan death in the West Indies. Nature 394:137-138
Goreau TJ, Macfarlane AH (1990) Reduced growth rate of Montastrea annularis following the 1987-88 coral bleaching event. Coral Reefs 8:211-215

Goreau TJ, Cervino J, Goreau M, Hayes R, and others (1998) Rapid spread of diseases in Caribbean coral reefs. Rev Biol Trop 5:157-171

Gotelli NJ (1988) Determinants of recruitment, juvenile growth, and spatial distribution of a shallow water gorgonian. Ecology 69:157-166

Guzmán HM, Cortés J (1984) Mortandad de Gorgonia flabellum Linnaeus (Octocorallia: Gorgoniidae) en la Costa Caribe de Costa Rica. Rev Biol Trop 32:305-308

Huston M (1985) Variation in coral growth rates with depth at Discovery Bay, Jamaica. Coral Reefs 4:19-25

Jokiel PL, Coles SL (1990) Response of Hawaiian and other Indo Pacific reef corals to elevated temperature. Coral Reefs 8:155-162

Jolles AE, Suvillan P, Alker AP, Harvell CD (2002) Disease transmission of aspergillosis in sea fans: inferring process from spatial pattern. Ecology 83:2373-2378

Kim K, Harvell CD (2004) The rise and fall of six-year coral fungal epizootic. Am Nat 164:S52-S63

Kim K, Lasker HR (1997) Flow-mediated resource competetion in the suspension feeding gorgonian Plexaura homomalla (Esper). J Exp Mar Biol Ecol 215:49-64

Kim K, Alker AP, Shuster K, Quirolo C, Harvell CD (2006) Longitudinal study of aspergillosis in sea fan corals. Dis Aquat Org 69:95-99

Lasker HR, Sánchez JA (2002) Astogeny and allometry of modular colonial organisms. In: Hughes RN (ed) Reproductive biology of invertebrates: Progress in asexual reproduction Vol XI. John Wiley \& Sons, New York, p 207-253

> Lasker HR, Boller M, Castanaro J, Sánchez JA (2003) Determinate growth and modularity in a gorgonian coral. Biol Bull 205:319-330

Lirman D (2000) Lesion regeneration in the branching coral Acropora palmata: effects of colonization, colony size, size and lesion shape. Mar Ecol Prog Ser 197:209-215

Morse DE, Morse-Duncan H, Tench RK (1981) Algal tumors in the Caribbean octocorallian, Gorgonia ventalina. Bull Mar Sci 32:399-409

> Mullen KM, Harvell CD, Alker AP, Dube D, Jordán-Dahlgren E, Ward JR, Petes LE (2006) Host range and resistance to aspergillosis in three sea fan species from the Yucatan. Mar Biol 149:1355-1364

> Nagelkerken IK, Smith GW, Bonair K, Bush P and others (1997) Widespread disease in Caribbean sea fans. II. Patterns of infection and tissue loss. Mar Ecol Prog Ser 160: $255-263$

Nugues MM (2002) Impact of a coral diseased outbreak on coral communities in St. Lucia: What and how much has been lost? Mar Ecol Prog Ser 229:61-71

> Oren U, Benayahu Y, Loya Y (1997) Effect of lesion size and shape on regeneration of the Red Sea coral Favia favus. Mar Ecol Prog Ser 146:101-107

> Pantos O, Cooney RP, LeTissier MDA, Barer MR, O'Donnell GO, Bythell JC (2003) The bacterial ecology of a plaguelike disease affecting the Caribbean coral Monstastrea annularis. Environ Microbiol 5:370-382

> Petes LE, Harvell CD, Peters EC, Webb AM, Mullen KM (2003) Pathogens compromise reproduction and induce melanization in Caribbean sea fans. Mar Ecol Prog Ser 264:167-171

Sebens KP (1984) Water flow and coral colony size: interhabitat comparisons of the octocoral Alcyonium siderium. Proc Natl Acad Sci 81:5473-5477 
Smith GW, Ives LD, Nagelkerken IA, Ritchie KB (1996) Caribbean sea fan mortalities. Nature 383:487

Toledo-Hernández C, Bones-González A, Ortiz-Vázquez OE, Sabat AM, Bayman P (2007a) Fungi in the sea fan Gorgonia ventalina: diversity and sampling strategies. Coral Reefs 26:725-730

Toledo-Hernández C, Sabat AM, Zuluaga-Montero A (2007b) Density, size structure and aspergillosis prevalence in Gorgonia ventalina at six localities in Puerto Rico. Mar Biol 152:527-535

Toledo-Hernández C, Zuluaga-Montero A, Bones-González A, Rodríguez JA, Sabat AM, Bayman P (2008) Fungi in healthy and diseased sea fans (Gorgonia ventalina): Is Aspergillus sydowii always the pathogen? Coral Reefs 27: 707-714

> Wilkinson OR (1999) Global and local threats to coral reef functioning and existence: review and prediction. Mar Freshw Res 50(8):867-878

Editorial responsibility: Charles Birkeland,

Honolulu, Hawaii, USA
Work TM, Richardson LL, Reynolds TL, Willis BL (2008) Biomedical and veterinary science can increase our understanding of coral disease. J Exp Mar Biol Ecol 346:36-44

Yoshioka PM (1994) Size-specific life history pattern of a shallow-water gorgonian. J Exp Mar Biol Ecol 184:111-122

Yoshioka PM (1996) Variable recruitment and its effects on the population and community structure of shallow-water gorgonians. Bull Mar Sci 59:433-443

Yoshioka PM, Yoshioka BB (1987) Variable effects of hurricane David on the shallow water gorgonians of Puerto Rico. Bull Mar Sci 40:132-144

Yoshioka PM, Yoshioka BB (1989) Effects of wave energy, topographic relief and sediment transport on the distribution of shallow-water gorgonians of Puerto Rico. Coral Reefs 8:145-152

Yoshioka PM, Yoshioka BB (1991) A comparison of the survivorship and growth of shallow water gorgonian species of Puerto Rico. Mar Ecol Prog Ser 69:253-260

Submitted: November 12, 2008; Accepted: July 26, 2009 Proofs received from author(s): October 10, 2009 